\title{
Phytoremediation potential of Allium cepa var. aggregatum on different soils contaminated with heavy metals
}

\section{Okunlola A. I.}

Department of Crop, Soil, and Pest Management, the Federal University of Technology, P.M.B 704, Akure, Ondo State, Nigeria.

Accepted 6 February, 2019

\begin{abstract}
The rapid industrialization in the urban cities of Nigeria has increased environmental pollution owing to increased human activities on energy reservoirs and unsafe agricultural practices resulting in heavy metals accumulation that are toxic to plants. In view of this, a research was conducted to investigate the phytoremediation potential of Allium aggregatum identified as a useful short-term test-system in biomonitoring of pollution on different soils contaminated with heavy metals. The experiment conducted of January to June 2016 in the screenhouse of the Department of Crop, Soil and Pest Management of the Federal University of Technology, Akure (FUTA) was laid out in a Complete Randomised Design (CRD). Seeds obtained from Songhai Farms Port Harcourt, Nigeria were sown into pots filled with soil taken from four different locations (dumpsite, mechanic workshop, effluence site, and forest) in January 2016. Data were collected on: plant height, number of leaves, stem girths. Initial and final soil chemical analyses were done on the soils taken from different sites, to determine the heavy metal concentration prior to and after the experiment. The content of $\mathrm{Mg}$ and Fe and follow heavy metals were determined; $\mathrm{Zn}, \mathrm{Pb}$ and $\mathrm{Cu}$. Results of the study indicated that the heavy metal concentrations in the soils were significantly reduced $(\mathrm{Pb}$ was completed eliminated). The percentage of unabsorbed metal concentration ( $\mathrm{Mg}, \mathrm{Zn}, \mathrm{Cu}$ and $\mathrm{Fe}$ ) varies from one soil sample to another. Further study is recommended to establish the phytoremediation potential of ornamental plants.
\end{abstract}

Keywords: Environmental pollution, remediation, ornamental, heavy metal, soils.

E-mail: okunlolaa1.hort@gmail.com. Tel: +234-8034435717.

\section{INTRODUCTION}

The soil as an essential part of natural ecosystems plays significant role in the geochemical cycle of elements. It has substantial functions as a filter, buffer, storage, and transformation compartment sustaining a relationship between the biotic and abiotic components of ecosystems (Kabata-Pendias and Pendias, 2001). The issues around environmental pollution have been on the rise in the past few decades with technogenic and anthropogenic activities as the primary sources (Kvesitadze et al., 2001). Hence, being a promising technology for addressing problems relating to soil contamination the phytoremediation has attracted increasing attention.
Phytoremediation is a technique that relies on the use of plant interactions (physical, biochemical, biological, chemical and microbiological) in polluted sites to mitigate the toxic effects of pollutants. The term heavy metals refer to any metallic chemical element that has a relatively high density and is toxic or poisonous to mammals at low concentrations. Examples of heavy metals include mercury $(\mathrm{Hg})$, cadmium $(\mathrm{Cd})$, chromium $(\mathrm{Cr})$, lead $(\mathrm{Pb})$ and Arsenic (As) (lenntech, 2004). These metals mentioned are known to significantly compromise the quality of soil and cause adverse effects to human when water or farm produce from such soils are used (Okunlola and Abdul-Azeez, 2018). This is one of the 
primary reasons why arable crops are not encouraged as phytoremediator. As urbanization continues to expand, arable land in the urban areas in Nigeria are used for building, leading to many in the urban cities cultivating on available land which are dumpsites, backyards, or free land around mechanic workshops. However, most of these abandoned waste dumpsites in many towns in Nigeria attract people as fertile ground for cultivating varieties of crops (Okunlola and Akinrinnola, 2014). The cultivated plants take up the metals as mobile ions present in the soil solution through the root. The uptake of the metals by crops results in the bioaccumulation of these elements in the plant tissues (Okunlola and AbdulAzeez, 2018). If the consumption of these metals through plant source is not carefully regulated, it may lead to accumulation in man with attendant health hazards and numerous other chemical influences in the environment (Olayiwola, 2011).

As research shifts from the use of arable crops in phyto-remediation process to finding different ways of removing toxic materials from the soils, ornamental plants could be a silver bullet to this challenge as it is not edible. Although, the test crop for this study is Allium cepa, a commonly consumed leafy vegetables in Nigeria and in some cases also used as an ornamental. Studies have also shown that it could be used as a short-term testsystem in biomonitoring of environmental pollution. Compared to other plants, these plants are more sensitive to environmental stressors. Different studies have been conducted on the use of ornamental plants to remove toxic metals from the soils. However, literature remains scanty on the use of shallot in phyto-remediation studies. Therefore, this research aimed to assess the phytoremediation potential of $A$. aggregatum on soil contaminated with heavy metals and the growth performance of shallot on the contaminated soil.

\section{MATERIALS AND METHODS}

The experiment was conducted at the screenhouse of the Department of Crop, Soil and Pest Management, FUTA. The experiment was conducted in the screenhouse and laid out in CRD. The seeds of shallot were obtained from Songhai Farms Port hart court, Nigeria. Soil samples were taken from four different sites (dumpsite, mechanic workshop, and effluence site and forest). Soils from different sites were taken from 0 to $15 \mathrm{~cm}$ soil depth. Representative samples were collected from areas corresponding to low, medium and high concentrations of metals according to the soil metal concentration information provided by the Oklahoma Department of Environmental Quality (ODEQ) (Beiergrohslein, 1998).

\section{Preliminary soil preparation}

All the soil samples were air dried for 5 to 6 days and mixed thoroughly to achieve homogeneity. The soils were sieve to reduce the particle size of the samples to $<2 \mathrm{~mm}$ using a sieve and nose mask was used to avoid inhalation of dust during sieving. Before planting, soil samples collected from different sites were analyzed for total heavy metal concentration. Soil analyses were then determined using (AAS) Atomic Absorption Spectroscopy, Buck Scientific 2011.

\section{Data collection}

Each pot was planted with four seeds. Two weeks after planting, the healthiest plant was retained in the pot. Watering was done daily and weeds were hand pulled. Data collection began three weeks after germination and was done weekly for eight weeks. Data were collected for plant height, stem girth and leaf numbers.

After eight weeks, soil analysis was done to determine the present heavy metal concentration in the soil in order to determine the percentage contamination reduction.

\section{Percentage contamination calculation}

The percentage contamination reduction was calculated using the formula below:

$\%$ Contamination reduction $=\frac{\text { initial value }- \text { final value }}{\text { initial value }} \times \frac{100}{1}$

\section{Data analysis}

The data were subjected to analysis of variance (ANOVA) using SPSS 17. Significant means were from each other using New Duncan's Multiple Range Test at $5 \%$ level of probability.

\section{RESULTS}

The results revealed significant differences in the plant height and number of leaves of $A$. aggregatum (Table 1) as well as perceptible reduction in heavy metals content was resulted in the soils (Table 2). Significant difference was not recorded for stem girth across the weeks of the experiment except in the first week (Table 1). $A$. aggregatum planted in topsoils gave the highest mean value for characters under study (Plant height, number of leaves, stem girth) across the weeks of the experiment, followed by soils from dumping site and effluent. The performance of $A$. aggregatum was poor on the mechanic soils as it gave lowest mean value for the characters recorded. Table 2 showed the percentage reduction in contaminated soil using $A$. aggregatum. It was observed that $A$. aggregatum was able to mitigate $\mathrm{Pb}$ from the soil in a more significant percentage except in mechanic soil where it was removed entirely,but copper $(\mathrm{Cu})$ out of the five elements in all the soil was also reduced to a smaller percentage except in mechanic soil where it was reduced at $8.6 \%$.

The percentage reduction in contaminated soil using $A$. aggregatum is presented in Table 2. The initial heavy metal concentration analyses that were conducted revealed that $\mathrm{Pb}$ was absent in the forest top soils and the $\mathrm{Cu}$ concentration in the soil was low compared to the concentration present in other soils. The phytoremediation potential of shallot was shown from the percentage reduction in contamination of heavy metal. 
Table 1. Effects of soils types on growth paramters of $A$. aggregatum as influenced by heavy metal concentration.

\begin{tabular}{|c|c|c|c|c|c|c|c|c|}
\hline \multirow{2}{*}{ Soil type } & \multicolumn{8}{|c|}{ Plant height (cm) per week } \\
\hline & 1 & 2 & 3 & 4 & 5 & 6 & 7 & 8 \\
\hline Top & $15.00 \pm 1.73^{\mathrm{C}}$ & $18.33 \pm 1.67^{c}$ & $21.67 \pm 2.40 c$ & $24.67 \pm 3.18^{c}$ & $27.00 \pm 2.52^{c}$ & $34.67 \pm 1.45^{\mathrm{cd}}$ & $41.00 \pm 0.58^{D C}$ & $49.33 \pm 2.60^{\circ}$ \\
\hline Dump & $12.67 \pm 1.33^{\mathrm{ab}}$ & $16.00 \pm 1.52^{\mathrm{bc}}$ & $21.00 \pm 2.00^{c}$ & $24.00 \pm 2.00^{c}$ & $26.67 \pm 3.76^{\mathrm{C}}$ & $33.33 \pm 1.67^{\mathrm{bc}}$ & $39.33 \pm 1.20^{\mathrm{bc}}$ & $43.67 \pm 2.40^{\mathrm{b}}$ \\
\hline Mechanic & $10.33 \pm 0.88^{a}$ & $12.00 \pm 0.58^{\mathrm{a}}$ & $14.00 \pm 0.58^{\mathrm{a}}$ & $15.33 \pm 1.45^{\mathrm{a}}$ & $18.67 \pm 0.88^{\mathrm{a}}$ & $20.67 \pm 0.88^{a}$ & $22.67 \pm 0.88^{a}$ & $25.00 \pm 1.45^{\mathrm{a}}$ \\
\hline \multirow[t]{2}{*}{ Effluence } & $10.67 \pm 0.88^{a}$ & $13.67 \pm 0.67^{\mathrm{D}}$ & $16.33 \pm 0.66^{\mathrm{b}}$ & $19.00 \pm 1.15^{\mathrm{ab}}$ & $21.00 \pm 1.15^{\mathrm{ab}}$ & $28.67 \pm 2.60^{\mathrm{ab}}$ & $36.00 \pm 3.79^{\mathrm{D}}$ & $42.33 \pm 4.26^{\mathrm{b}}$ \\
\hline & Number of leaves & & & & & & & \\
\hline Top & $6.00 \pm 1.00^{\mathrm{cd}}$ & $11.00 \pm 3.05^{\mathrm{d}}$ & $15.33 \pm 4.26^{a}$ & $17.67 \pm 3.71^{\mathrm{d}}$ & $20.33 \pm 3.93^{d}$ & $24.00 \pm 4.51^{d}$ & $28.00 \pm 5.00^{\mathrm{d}}$ & $31.67 \pm 5.70^{c}$ \\
\hline Dump & $7.00 \pm 2.08^{a}$ & $10.33+1.86^{\mathrm{ca}}$ & $14.67 \pm 2.33^{\mathrm{ca}}$ & $15.33+3.18^{\mathrm{ca}}$ & $16.67 \pm 4.91^{\mathrm{ca}}$ & $18.00 \pm 7.36^{c}$ & $23.67 \pm 6.64^{c}$ & $31.67 \pm 8.45^{\mathrm{c}}$ \\
\hline Mechanic & $1.33 \pm 0.33^{a}$ & $2.00 \pm 0.00^{\mathrm{a}}$ & $2.67+0.33^{\mathrm{a}}$ & $3.67+0.33^{a}$ & $4.33+0.88^{\mathrm{a}}$ & $4.67 \pm 1.20^{\mathrm{a}}$ & $567+120^{a}$ & $6.67+120^{a}$ \\
\hline \multirow[t]{2}{*}{ Effluence } & $4.00 \pm 1.15^{\mathrm{b}}$ & $6.67 \pm 3.06^{b}$ & $9.33 \pm 2.03^{b}$ & $9.00 \pm 2.52^{b}$ & $12.00 \pm 2.3 b^{c}$ & $13.67 \pm 2.60^{b}$ & $7.33 \pm 7.26^{\mathrm{ab}}$ & $16.67 \pm 3.18^{b}$ \\
\hline & Stem girth (cm) & & & & & & & \\
\hline Top & $1.93 \pm 0.58^{\mathrm{ab}}$ & $2.23 \pm 0.50^{\mathrm{a}}$ & $2.57 \pm 0.47^{\mathrm{a}}$ & $2.80 \pm 0.35^{\mathrm{a}}$ & $3.07 \pm 0.33^{a}$ & $3.27 \pm 0.33^{a}$ & $3.50 \pm 0.31^{a}$ & $3.73 \pm 0.28^{\mathrm{a}}$ \\
\hline Dump & $1.93 \pm 0.58^{a}$ & $2.10 \pm 0.61^{a}$ & $2.27 \pm 0.61^{a}$ & $2.77 \pm 0.47^{\mathrm{a}}$ & $2.97 \pm 0.55^{a}$ & $3.17 \pm 0.55^{a}$ & $3.37 \pm 0.55^{\mathrm{a}}$ & $3.50 \pm 0.52^{a}$ \\
\hline Mechanic & $0.93 \pm 0.34^{a}$ & $1.17 \pm 0.32^{\mathrm{a}}$ & $1.30 \pm 0.35^{\mathrm{a}}$ & $1.57 \pm 0.35^{\mathrm{a}}$ & $1.87 \pm 0.35^{\mathrm{a}}$ & $2.10 \pm 0.40^{\mathrm{a}}$ & $2.33 \pm 0.46^{\mathrm{a}}$ & $2.50 \pm 0.47^{\mathrm{b}}$ \\
\hline Effluence & $1.63 \pm 0.15^{\mathrm{a}}$ & $1.90 \pm 0.10^{\mathrm{a}}$ & $2.00 \pm 0.12^{\mathrm{a}}$ & $2.20 \pm 0.17^{\mathrm{a}}$ & $2.40 \pm 0.17^{\mathrm{a}}$ & $2.57 \pm 0.20^{\mathrm{a}}$ & $2.83 \pm 0.23^{a}$ & $3.10 \pm 0.25^{a}$ \\
\hline
\end{tabular}

Each value is mean \pm standard error of three replicates. Values followed by the same letters are not significantly $(p<0.05)$ different from each other using New Duncan's Multiple Range Test.

Table 2. Percentage reduction in contaminated soils.

\begin{tabular}{|c|c|c|c|c|}
\hline Soil type & Contaminant & Initial contaminant before planting & Final contaminant after planting & $\%$ reduction in contamination \\
\hline \multirow{5}{*}{ Top soil } & $\mathrm{Mg}$ & $278.00 \pm 2.88^{\text {ef }}$ & $149.00 \pm 1.63^{\mathrm{de}}$ & $46.40 \pm 0.68^{\mathrm{cd}}$ \\
\hline & $\mathrm{Zn}$ & $69.50 \pm 1.86^{c}$ & $35.00 \pm 0.85^{\mathrm{ab}}$ & $49.64 \pm 0.58^{d}$ \\
\hline & $\mathrm{Pb}$ & - & - & - \\
\hline & $\mathrm{Cu}$ & $6.00 \pm 3.14^{\mathrm{a}}$ & $2.00 \pm 0.88^{\mathrm{a}}$ & $66.67 \pm 0.67^{\text {ef }}$ \\
\hline & $\mathrm{Fe}$ & $69200.00 \pm 2.18^{j}$ & $19200.00 \pm 3.23^{h}$ & $72.25 \pm 1.45^{\mathrm{fg}}$ \\
\hline \multirow{5}{*}{ Dumpsite } & $\mathrm{Mg}$ & $245.00 \pm 0.57^{\mathrm{de}}$ & $152.00 \pm 1.45^{\mathrm{e}}$ & $37.96 \pm 0.22^{b c}$ \\
\hline & $\mathrm{Zn}$ & $350.00 \pm 2.25^{9}$ & $81.00 \pm 2.18^{c}$ & $76.86 \pm 2.12^{f}$ \\
\hline & $\mathrm{Pb}$ & $32.00 \pm 2.34^{b}$ & $6.00 \pm 2.54^{\mathrm{a}}$ & $81.25 \pm 2.63^{g}$ \\
\hline & $\mathrm{cu}$ & $377.00 \pm 1.73^{\mathrm{g}}$ & $41.00 \pm 3.44^{b}$ & $89.12 \pm 1.42^{9}$ \\
\hline & $\mathrm{Fe}$ & $46850.00 \pm 2.86^{i}$ & $8660.00 \pm 2.85^{9}$ & $81.52 \pm 2.34^{g}$ \\
\hline \multirow{5}{*}{ Effluence } & $\mathrm{Mg}$ & $300.00 \pm 4.01^{f}$ & $120.00 \pm 2.79^{d}$ & $60.00 \pm 2.45^{\mathrm{e}}$ \\
\hline & $\mathrm{Zn}$ & $293.00 \pm 2.43^{\dagger}$ & $105.00 \pm 2.64^{\mathrm{cd}}$ & $64.16 \pm 2.18^{e}$ \\
\hline & $\mathrm{Pb}$ & $20.00 \pm 0.66^{a}$ & $3.00 \pm 2.54^{\mathrm{a}}$ & $85.00 \pm 0.76^{g}$ \\
\hline & $\mathrm{cu}$ & $377.00 \pm 1.54^{\mathrm{g}}$ & $41.50 \pm 1.96^{b}$ & $88.99 \pm 0.55^{9}$ \\
\hline & $\mathrm{Fe}$ & $12300.00 \pm 2.78^{h}$ & $5540.00 \pm 2.35^{\dagger}$ & $54.96 \pm 2.15^{\mathrm{de}}$ \\
\hline
\end{tabular}


Table 2. Continues.

\begin{tabular}{clccc}
\hline & $\mathrm{Mg}$ & $267.00 \pm 1.16^{\mathrm{e}}$ & $146.00 \pm 3.27^{\mathrm{de}}$ & $45.32 \pm 1.23^{\text {cd }}$ \\
Mechanic & $\mathrm{Zn}$ & $216.00 \pm 3.24^{\mathrm{d}}$ & $82.00 \pm 2.56^{\mathrm{c}}$ & $62.04 \pm 2.15^{\mathrm{e}}$ \\
& $\mathrm{Pb}$ & $26.00 \pm 2.19^{\mathrm{ab}}$ & - & $100.00 \pm 0.00^{\mathrm{h}}$ \\
& $\mathrm{Cu}$ & $17.50 \pm 2.32^{\mathrm{a}}$ & $16.00 \pm 2.45^{\mathrm{a}}$ & $8.57 \pm 0.32^{\mathrm{a}}$ \\
& $\mathrm{Fe}$ & $42650.00 \pm 1.28^{\mathrm{i}}$ & $27850.00 \pm 2.18^{\mathrm{h}}$ & $34.70 \pm 1.73^{\mathrm{b}}$ \\
\hline
\end{tabular}

Each value is mean \pm standard error of three replicates. Values followed by the same letters are not significantly $(p>0.05)$ different from each other.

There was a significant reduction in the $\mathrm{Pb}$ concentration as soils from the mechanic workshop recorded 100 percent reduction followed by effluence soils (85\%) and dumpsite $(81 \%)$. Soils from the mechanic workshop had the lowest Fe metal concentration (42650) among other soil types, approximately $35 \%$ of the initial Fe concentration was reduced from the soil.

\section{DISCUSSION}

The reduction in heavy metal concentration in the soils is an indication that a significant amount of metals tested for might have been absorbed into the plant's parts. Most probably, the strong growth retardation observed in soils of mechanic and effluent sites which had the highest $\mathrm{Pb}$ content was related to efficient accumulation of this element in the plant tissues, with special regards to bulbs.

Heavy metal analysis of the soils revealed that soils from the mechanic workshop had the highest percentage of heavy metals $(\mathrm{Fe}, \mathrm{Pb}, \mathrm{Zn})$, which could result the low performance of $A$. aggregatum. Nevertheless, the result from this work indicated that the Shallot planted on topsoil had a very high yield, followed by the effluence, dumpsite and mechanic soil. Though literature remains scanty on the phytoremediation potential of $A$. aggregatum, Okunlola and Abdul-Azeez (2018) revealed that environmental factors of a particular geographical location might have a significant effect on the growth and performance of plants on toxic soil.

\section{Conclusion}

The study indicated that heavy metal concentrations in the soils were significantly reduced, although none of the heavy metals was completely remediated except $\mathrm{Pb}$ in soil from mechanic site, and the yield of shallot varied among the soils. Topsoil recorded the highest yield followed by the effluence while soil from mechanic workshop recorded the lowest yield. Since the heavy metals were deposited in the bulbs, which is also an edible portion of the plant, the use of shallot for phytoremediation should be discouraged. However, further study is recommended to establish the phyto-remediation potential of other plants.

\section{REFERENCES}

Beiergrohslein E, 1998. The use of surfactants in removal of zinc, lead and cadmium from contaminated soils.

Kabata-Pendias A, Pendias H, 2001. Trace Elements in Soils and Plants. CRC Press, New York, $432 \mathrm{p}$
Kvesitadze Gl, Kalandiya AG, Papunidze SG, Vanidze MR, 2001. Identification and quantification of ascorbic acid in kiwi fruit by high-performance liquid chromatography. Appl Biochem Microbiol, 37: 215-218.

Lenntech Water Treatment and Air Purification, 2004. Water Treatment, Published by Lenntech, Rotterdamseweg, Netherlands. www.excelwater.com/thp/filters/WaterPurification htm

Okunlola Al, Abdul-Azeez AA, 2018. Assessment of Heavy Okunlola Al, Abdul-Azeez AA, 2018. Assessment of Heavy
Metal Accumulation in Vegetables Irrigated with Water from Metal Accumulation in Vegetables Irrigated with Water from
Different Sources. Proceedings of 6 th NSCB Biodiversity Conference; Uniuyo 2018 (160 - 163 pp).

Okunlola Al, Akinrinnola O, 2014. Effectiveness of botanical formulations in vegetable production and biodiversity preservation in Ondo State, Nigeria. J Horticul Forestry, 6(1): 6-13.

Olayiwola OA, 2011. An assessment of soil heavy metal pollution by various allied artisansplants. Biotechnology, 13: $468-475$.

Citation: Okunlola Al, 2019. Phytoremediation potential of Allium cepa var. aggregatum on different soils contaminated with heavy metals. Net J Agric Sci, 7(1): 30-33. 